\title{
Attitude Orientation and Specific Needs of Secondary Vocational School Teachers Working with Pupils from Disadvantaged Backgrounds
}

\author{
Viola Tamášová* \\ Department of School Pedagogy and Psychology, DTI University, Slovakia
}

Submission: May 18, 2020; Published: June 29, 2020

*Corresponding author: Viola Tamášová, Department of School Pedagogy and Psychology, DTI University, Dubnica nad Váhom, Slovakia (EU)

\begin{abstract}
Introduction: The author of the theoretical study wishes to clarify the situation regarding support for the education of pupils from socially disadvantaged backgrounds by teachers at secondary vocational schools from the teacher's point of view, and from the aspect of stress factors in the pedagogical process. One of them is the mental health of the teacher. Most of society wants equal education opportunities for every pupil, but in practice this is not so simple to achieve. Therefore, ways are being sought for compensating for or eliminating these inequalities. Educators are among those able in the field of education to help pupils with special educational needs. Very often, this requires increased efforts from them, a sensitive approach, and above all, sufficient knowledge in the field of integrated and inclusive education. The theoretical study is a partial output of the solution to the project VEGA No.1/ DTI 0142/19 2019 - Psychoeducational dimension of secondary school pupil inclusion, supported by the Ministry of Education, Slovakia.
\end{abstract}

Purpose: The main aim of the theoretical study is to clarify the issues regarding the special needs of educators who work with and teach pupils from socially disadvantaged backgrounds. These pupils grow up in an unstimulating environment and need help to be able to fully integrate into majority society. The partial goals of the study include the issues of defining integration / inclusion of children, and explanation of the specifics of pupils from disadvantaged social backgrounds, and proposals to support their education in an inclusive educational environment.

Methods: Since this is a professional, theoretical study, it uses theoretical methods with the aid of which conclusions of a theoretical nature were reached. The processing required intensive and time-consuming study of literature and other documents, with subsequent analysis, synthesis and comparison, induction and deduction, generalisation, and forecasting, with the focus placed on the mental processing of knowledge and scientific facts.

Conclusion: Collaborative work and collegiality in an inclusive school environment should be clearly targeted, planned and reflected. This means that teachers, special educators, teaching assistants and non-teaching staff should actively work with management to develop the school as an institution that offers inclusion. Teamwork of school staff represents for pupils a model of collegial, partnership cooperation of the learning community in the form of democratic governance. And to take full advantage of equal opportunities for education, it is necessary to support the creation of a stimulating and functional environment for learning and for working in the school environment equally for everyone.

Keywords: Teachers' specific needs; Socially disadvantaged secondary school pupil; Education actors; Integration; Inclusion

\section{Introduction}

Many children currently live in an unstimulating or unsuitable environment and need help on the path to a good quality life. Most of society wants equal education opportunities for every pupil, but in practice this is not so simple to achieve. For this reason, ways are being sought for compensating for or eliminating these inequalities. Educators are among those who can help such individuals in the field of education [1]. Very often, this requires increased efforts from them, a sensitive approach, and above all, sufficient knowledge in this field [2]. In this study, we want to clarify the situation regarding support for education of children from socially disadvantaged backgrounds by teachers at secondary vocational schools from the teacher's point of view and from the aspect of stress factors in the pedagogical process. One of them is the protection of the teacher's mental health. If teachers do not take sufficient care of their mental health, or neglect it completely, they may very quickly become exhausted and experience burnout syndrome. In the framework of the population of Slovakia and the Czech Republic (EU) roughly 3 - 5\% of pupils drop out of the compulsory schooling before reaching the ninth year of primary 
education. In most cases this concerns pupils - children from socially disadvantaged and marginalised backgrounds. Many of these pupils, though, can complete their education at practical vocational schools. Secondary vocational education provides pupils a successful, responsible and meaningful personal journey through life, including civic and working life, because it is based on four goals: "learning to know, learning to work and act, learning to be - understand one's own personality and its shaping, learning to live together - learning to live with others" and, together with key competences, they help achieve the overall goals of education at secondary vocational school. The above, though, is not always straightforward. What are the specifics of integrated / inclusive education [3]. provided to pupils with a certain disadvantage?

\section{Integrated / Inclusive Education in the Context of the Secondary School}

Around the world, integrated / inclusive education has undergone several years of development and has a rich history [4]. It is about society's relationship to individuals requiring special care [5], and which has been developing in relation to the structure of society in a particular area, the degree of thinking, morality and norms of social life, according to Bartoňová M \& Vítková M [6] and Zelina M [7]. Integrated education was first applied to people with physical or mental disabilities, while inclusion, also applied to people otherwise disadvantaged, came along only in the course of the following years [8], especially with the development of special pedagogy and special education. Integration can be understood as the integration of the greatest possible number of individuals into the ordinary life of majority society. At present, integration is understood mainly from the aspect of integrating pupils with special educational needs into the environment of ordinary school facilities. Integration has many positive aspects for these pupils, for instance it can be seen here that intact pupils routinely encounter the issues of disability / disadvantage daily that they previously had not had knowledge of. Conversely, for a child with special educational needs, intact classmates can be a form of motivation. Another advantage lies in the constant contact of the pupil with their own family because they are not separated from their family, as used to happen in the past. An integrated pupil has the choice of several options, and particularly has the opportunity to gain more experience with integration into majority society [9].

The definition of inclusion first appeared in the 1990s and is still one of the most discussed pedagogical phenomena in contemporary European pedagogy. Inclusive pedagogy, is, according to Lechta [10], "a challenge to the symbiosis of ordinary and special education." At present, in Slovakia and abroad, we can discern a three-dimensional notion of inclusive education, in comparison with integration, as frequently written about by M Horňáková [11]. According to her, in this way inclusion can: 1. be identified with integration, or be understood as, 2. enhanced "optimised" integration, or 3. a new quality of approach to children with disabilities, different from integration - as unconditional acceptance of all children's special needs. The understanding of inclusion is correct, according to Horňáková [11], only in the third sense, because otherwise this would be a duplication of terms. In Germany, to differentiate the terms from one another, as stated by Merz-Atalik [12], the concept "integration" is understood as a synonym of the concept "assimilation", which has a meaning completely different from "inclusion". Likewise, the UN Convention from 2006 (Convention, 2006) in the point on education calls for an "inclusive education system" as an educational concept.

Integration, according to Mittler [13], involves preparing pupils for their integration into mainstream schools - the pupil adapts to school, while there is no change to the school to be able to perceive pupils' greater heterogeneity and diversity of pupils. In contrast, inclusion requires, according to [13] and Wade [8], radical reform of school education in the curricular area, in the field of assessment and in creating groups of pupils. Inclusion accepts diversity in terms of gender, nationality, race, language, social background, level of performance, or disability / disadvantage. Inclusive pedagogy is then specifically focused on all pupils, irrespective of linguistic, cultural, ethnic differences [7] or differences in the economic status of the family, gender and abilities. Pupils can be educated with the peers in ordinary classes, and this is obviously a wider population than just traditionally perceived pupils with a disability / disadvantage, or at-risk pupils. Inclusion, therefore, has both a pedagogical and social plane, as state Mittler [13] and Barnová [14].

\section{Specifics of pupils from socially disadvantaged backgrounds}

Felcmanová L, Habrová M [15, p.8] characterised social disadvantage as a category, denoting a broad scale of causes of school failure among pupils due to non-health reasons, lying in the child's natural social background or stemming from other circumstances in their life outside of school. The child cannot influence these facts and they become a burden for the child in another social reality, in our case, the school environment.

The authors Felcmanová L Habrová M [15] consider a socially disadvantaged pupil mainly as being an individual who:

i. lives in an environment where he/she is not sufficiently supported for education over the long term (e.g. due to insufficient material background, unsatisfactory housing conditions, lengthy commute to school, lack of interest by the child's legal representatives, conflicts in the family, etc.).

ii. lives in an environment of socially excluded localities, or localities at risk of social exclusion,

iii. is disadvantaged in education due to belonging to an ethnic group (in Slovakia and the Czech Republic, the Roma group [7]), or ethnic group, or specific social environment, particularly if the disadvantage is associated with insufficient knowledge of the language of instruction in comparison with other pupils in the 
class, and this due to using a different language, or specific form of the language of instruction in the pupil's home environment.

There are many aspects for determining social disadvantage. Specific aspects can be divided into the following levels, according to Felcmanová L, Habrová M [15]:

i. the individual - e.g. linguistic difference, different sexual orientation, neglected appearance.

ii. families - e.g. incidence of physical or sexual abuse, neglect, dysfunctional family, different lifestyle, parents' high workload, incomplete family;

iii. social environment - e.g. socially excluded localities, threats of socio-pathological phenomena;

iv. socio-economic status - e.g. poverty, loss of material background due to excessive debt, migration, unsatisfactory housing conditions, cultural, linguistic, national or religious difference.

In consequence of social disadvantage, families may face isolation and segregation, stereotypes from the majority society, and a negative assessment of their social standing. The pupil, due to his/her family's handicap, is then stigmatised [16] in the educational process. His potential for development is often overlooked or suppressed [17], which significantly impedes his/her motivation, possibilities and resulting abilities. This deepens the social disadvantage and gives rise to a vicious circle, from which it is difficult to break out, and which significantly impedes the pupil's motivation, options and abilities in further development, according to Trnavský J [18]. It is necessary that a pupil coming from such an environment be provided support for fulfilling his/her educational potential (and not just his/her) so that he/she has the opportunity to possibly continue in further education and has the chance to seek qualified and appreciated work. In the conditions of both Slovak and Czech school systems, socially disadvantaged pupils form a large group [19], which is broken down by several factors: biological factors, environment and ethnic minorities that determine their disadvantages.

\section{Support for education of pupils with special educational needs in an inclusive educational environment}

Slovakia occupies first place among European countries in the share of primary school pupils educated in a special stream of education [3]. The long-term high proportion of children learning in separate schools and classes intended for pupils with the same or similar type of disadvantage or talent is, though, at variance with Slovakia's international commitments and with trends directed toward support for education of all children in the natural community in which they live [20]. At present, only half of children and pupils diagnosed with special educational needs are educated together with other children in classes at mainstream schools. Although the share of individually integrated children has increased over the past ten years, the number of children in special schools and special classes has long remained unchanged [20]. This points to the relative stability of the capacities of the special education system, and also to the persistent obstacles on the side of mainstream schools to react to the naturally occurring diversity among children. At the same time, the flow of mainstream and special education is impenetrable and separated. Special schools and classes are not used as a tool for temporary support of a child, but to a large degree they represent a permanently separate education path, down which most children start right at the beginning of their school attendance, with only a very small percentage of them being subsequently integrated in classes or schools of mainstream education. This is problematic also for reason that, according to Hapalová [20], more than half of pupils in special schools are children from excluded Roma localities and children from families afflicted by poverty. Moreover, graduating from a special school for most of them means a dead end in education, and thus also greater difficulty with progressing in their personal and working life in the future.

Although the segregation of children in education is in breach of international conventions, EU directives, and also with Slovak legislation, some $63 \%$ of Roma children in Slovakia are educated in classes in which all or most pupils are Roma [17]. The education of children from excluded Roma localities in separate classes and schools is not problematic just from a human-rights point of view but may be one of the causes of the long-term weaker education results of these children. At the same time, in the case of separate education of children from excluded localities and children from the majority population, both groups are deprived of the possibility of developing social competences and mutual contact, which is key for their future coexistence, and not just in a particular municipality or town, but also in society [21]. A problem at the level of secondary schools is the existence of allocated workplaces, located in close proximity to excluded localities.

\section{Actors of Integrated / Inclusive Education in Secondary Schools}

The main actors of inclusive education are pupils, educators/ teachers and other professional non-teaching staff, and last but not least, parents [12]. Among pupils this represents both a majority - intact group of pupils, and pupils with specific educational needs (SEN). From a didactic point of view, they do not form a homogeneous whole, even though they are characterised as intact. Nonetheless, it is important, as Matuška O [22] points out, that intact pupils be involved in the inclusive process, in creating friendly, partner and positive attitudes and relationships with pupils with special educational needs. Existing stereotypes, stigmas and prejudices significantly influence (also negatively) this model of creating positive attitudes, according to Levterová D [23]. 


\section{Teachers in an inclusive teaching process and their specific needs}

The primary position in the teaching process in a mainstream class, as well as in an integrated / inclusive class, is held by the class teacher [24]. Alongside his/her traditional roles and main duties - communication, diagnostic, counselling, organisational, he/she has extraordinary duties in relation to SEN pupils [22, p. 122], which include:

i. acquiring and gathering diagnostic information about SEN pupils, and evaluating them with colleagues;

ii. coordinating the planning and implementation of inclusive education for these pupils in the class;

iii. as a team, drawing up an individual education plan for each pupil in the class, monitoring its implementation and, if necessary, making a correction to the plan and its implementation;

iv. preparing, planning and cyclically holding joint meetings of actors of the inclusive process in the class, solving any problems in the teaching and evaluating their results;

v. taking responsibility for keeping pedagogical documentation on the inclusion / integration, positively directing the class collective (also outside the classes) and coordinating cooperation with all actors in the inclusive process [25].

An important member of the professional team in the inclusive educational process is the school's special education teacher (not every school employs one). A special education teacher covers a broad range of activities, but it is necessary to emphasise his/her individual therapeutic, corrective activities, counselling for pupils - how to learn, how to use compensatory aids, etc., advice to parents in educational issues, counselling for teachers/educators - colleagues in matters of using teaching and educational methods, in issues of directing and managing education [26]. In addition, a special education teacher has a close relationship with the majority group of pupils in and outside the teaching process. He/she works in partnership with pupils of the secondary and tertiary stage of school, in solving their personal problems, tasks, helping them in shaping their attitudes, emotions, social sensitivity, tolerance, but also in the occurrence of sociopathological phenomena. $\mathrm{He} /$ she cooperates with the school psychologist, specialist doctors, Master of Vocational Training and parents.

When we examine the teacher's function in the inclusive process - meaning an inclusive teacher, a decisive role, alongside the function of an extended interaction relationship, is played by his/her personality attributes and professional abilities and competences. We will choose several important ones:

i. The teacher's competences in teaching and education; appropriate diagnostic, communication, pedagogical psychological, personality competences in the field of the development of both SEN and intact pupils. ii. Standards of teachers' performance, particularly their engagement in achieving effective teaching and monitoring of pupils' learning and their assessment, particularly their formative [27-29];

iii. The ability of expert activity in assisting inclusive / integrated activity. The teacher's decision-making and selfreflection are important factors in managing the inclusive teaching process.

iv. Mastering the basics of special pedagogy in the field of the prevention, diagnosis and intervention of special education counselling in the discipline that concerns its pupils with special educational needs. In the stage of preparation, implementation and evaluation of teaching, the teacher communicates and consults with the special education teacher.

The curriculum of SEN pupils must be adapted to their requirements [30], but in so doing it is necessary to maintain the principle of approximating it as closely as possible to the curriculum of intact pupils. According to Putnam [31], of the principles to respect, the main four are: - modification of the form by which pupils achieve a set goal, - modification of how pupils are familiarised with new material, - reduced number of assigned tasks and reduced expected level of the pupil's performance. Pupils proceed according to an Individual Education Plan (IEP), in the compilation of which it is necessary, according to Lang and Berberich [32], that the team of educational actors answer several questions, such as: What is the pupil capable of, what can he/she do - what can't he/she do?; What are his/her learning needs? How should one prepare for a lesson in order that his/her educational needs are satisfied? Who will he/she cooperate with?; What can the teacher and other team members expect from implementation of the IEP?

What is the actual benefit of the individual education plan for a SEN pupil and for the teacher? According to the mentioned authors, the benefit lies mainly in: a clear specification and ranking of priorities in care for the pupil, and a plan of how his/ her special needs will be met

i. a programme of activities focused on a specific pupil;

ii. taking into account the pupil's learning style;

iii. closer professional relationships between members of the inclusive education team;

iv. realistically achievable educational goals and specific tasks focused on developing the pupil's personality; [32, cited in 22, p. 127].

Besides the class teacher and other teachers, an important role is also played by other actors. "Assistance and support activities" for a pupil in the framework of inclusive education is performed by the teacher's assistant. The teacher's assistant focuses on overcoming barriers in movement, communication, 
learning and in other difficulties that occur during the teaching day. Without a teacher's assistant in an inclusive school, pupils with multiple disabilities, motoric disabilities, or severely socially disadvantaged pupils would not be able to be successfully educated together with the majority, intact population of pupils. This requires the special-pedagogical knowledge and professional skills of an assistant with the proper training and with the ability to withstand the burden $[22,33]$.

The secondary school principal and his/her deputy should create an "inclusive spirit" at the school by introducing common philosophical concepts into a change in the system of educational activities, progressively involving all school staff. Senior teaching staff create the necessary staffing, material and organisational conditions for implementation of the inclusive process [34] and also have the task of gaining supporters for the inclusion project for further education and application of pupils with special educational needs.

Other professional actors in the inclusive / integrated educational process are school psychologists, educational or career advisors, methodologists of preventive activity, social workers and specialist doctors. Their professional contribution lies mainly in their comprehensive input, continuous and output diagnostic activity, in evaluating the effectiveness of inclusive / integrated education, and in their advisory activity. The education of pupils with different living conditions and different cultural backgrounds is often associated with the endeavour for equal access to education for all without distinction. This concept also became a priority goal of Slovak and Czech education policy and education in the framework of inclusion, and is codified in the Education Act $(245 / 2008$ Coll. the Education Act of the Slovak Republic, and 561/2004 Coll. the Education Act of the Czech Republic). An essential step in the framework of inclusive education in the conditions of a secondary vocational school is the professional application of school leavers with special educational needs in practice. In choosing a secondary school field of study, it is necessary to take account not just of the pupil's abilities and skills, but also the possibility of their subsequent application in the labour market [6].

\section{Specific needs of teachers in the educational process}

Teachers must fulfil, as a first condition, the requirement for professional qualification that corresponds to the requirements for performing this profession. In order for a teacher to be able to fulfil the plans of the Ministry of Education of a given country and be prepared for their implementation in practice, and at the same time be able to meet requirements according to the respective Framework or School Education Programme, including for SEN pupils, their professional and personal characteristics [35], must correspond to a certain profile, which develops and changes over the course of time and length of teaching practice. The model for teachers' professional development distinguishes five different stages says Berliner [1]. According to this model, there is the novice teacher, the novice passes through to the advanced beginner teacher phase through to the competent teacher. A smaller share of teachers then move on to the proficient teacher phase, after which there comes the expert teacher phase. The space for the development of professional knowledge and skills varies from teacher to teacher, but the estimates for achieving expertise in teaching indicate an interval of five years' or more teaching practice.

Professional competences are key to the quality performance of a teacher's profession. In connection to the rapid changes, the development of modern technologies and new knowledge, the importance of continual professional education and development is growing. Knowledge and appropriate use of teaching methods represents a kind of basis, says Tomková A et al. [36], which further encompasses the knowledge of a pedagogical nature in the field taught, and its link to didactics, knowledge of curricular documents and their content, knowledge of the goals of education, the educational environment, knowledge about pupils and, last but not least, of the teacher's own limits. In order for a teacher to be able to properly meet all the requirements placed on him/her, he/she needs to have the possibility of personal and professional development within and outside the organisation. Systematic education in a school organisation has a whole range of functions: development and integration, innovation, adaptation, motivation, and many others. It can also be understood as a means of preventing a high degree of staff turnover within the organisation [37]. Support for teachers' needs in the framework of a learning school focuses, inter alia, on their professional development and increasing their skills and expertise [38,39]. Emphasis here is placed on the pupil's cognitive development and improving the quality of his/her learning, the ability to interconnect information, higher levels of thinking, etc. On the other hand, the principles of community schools also relate to personality and social aspects of the pupil's development and are oriented more on values, such as the educational function, solution of social problems, the emotional sphere, etc. Support for teachers in community schools then leads, for example, to the development of their communication skills with parents, issues of counselling and work with pupils with specific educational needs in all forms.

At the general level it can be stated, based on the ideas of Kasíková H [40], that the basic need of teachers is mainly the development of their skills, knowledge and expertise. These specific needs can be met by means of a great variety of activities. The professional development of an individual is not just a matter for one teacher, but also for other teachers and the whole school facility. An important role is played by teachers' cooperation within a school, representing one of the conditions for teachers' effective professional development. The basis for the professional development lies in the conditions set by the school management. The role of the school is to support common learning, planning 
and implementation of this learning, and to exploit the benefits of the cooperation and collegiality of its participants. Positive results in the field of professional development can be found in the field of workplace learning and intergenerational learning, as opportunities for the teachers' professional development.

\section{Workplace learning and intergenerational learning}

In a broader sense, workplace learning consists of learning in workplace, learning for workplace and learning through the workplace [41,42]. A characteristic feature of workplace learning is the spontaneous reactions in the framework of social interactions between staff - e.g. including both teaching and non-teaching school staff. Workplace learning is most often implemented by means of specifically focused training, but also by means of general education in the broader sense of the word. In addition, learning through the workplace is learning mediated on the basis of the employment relationship between the worker and the organisation, e.g. school. This concerns education programmes, training, courses, etc. [43]. The intersection of these three basic types of learning is then learning for the workplace. This specifically is a combination of formal learning, non-formal learning and informal learning. Experts also state that workplace learning is three-quarters performed via non-formal learning, in the form of self-education, mentoring or information transfer. Formal learning provides for the acquisition of a wide variety of certificates.

\section{Intergenerational learning}

Another manner of teachers' development is intergenerational learning. This is a specific kind of learning, which can be defined as follows: "Learning processes that occur mainly between people of different generations. Between parents and children, grandparents and grandchildren, among other adults and children, or adolescents, etc." [44,45]. In a more general way, it can be described as a set of activities and knowledge of a theoretical, research and application nature, which is oriented on a certain benefit for each generation involved. It can mean a meeting, mutual exchange of information between people of different generations. It must be emphasised, according to Rabušičová $\mathrm{M}$ et al. [46], that this transfer is two-way. Intergenerational learning takes place in the same way in the school environment, via the concept of a mentoring teacher, observations in classes, formal structure and organisation, or also through mentoring. The key content of intergenerational learning lies in teaching methods, approaches to work or life, approaches to modern technologies and organisation of the school context. Such content then spreads from the older to the younger generation, providing for a transfer of information and experience from the field of the organisation of teaching, or the functioning of a school as an institution, or from the younger generation to the older generation, and this particularly in the field of using modern technologies, but also both ways, for example in the field of effective teaching methods.

\section{Collegial support at school}

Collegial support and its forms can also be implemented in the school environment. Together with passing on experience, it forms a prerequisite for a functioning learning and cooperating school, according to Pol M [47]. Collegial support, in addition to sharing experiences, information or problems [48], forms the content of the concept collegiality, which can and needs to be deployed in an integrated / inclusive school. In the environment of such schools, collegiality should be clearly targeted, planned and reflected, emphasises Lazarová B [49]. This means that teachers, special education teachers, teachers' assistants and non-teaching staff should actively work with management to develop the school as an institution that offers inclusion.

Collegiality must, though, meet certain conditions, such as the principle of voluntariness, which means that no one should be forced into anything to not suppress a teacher's development, which would have the opposite effect.

Collegiality should not suppress individuality. We can distinguish 4 levels of collegiality:

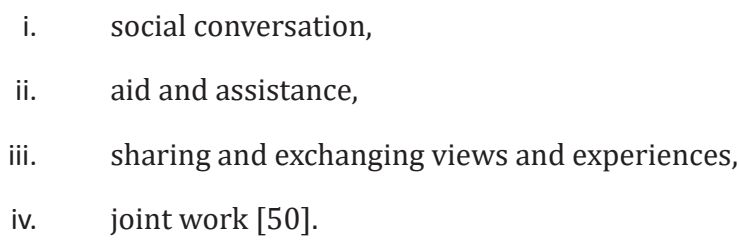

Jointworkcan be described as thestrongestform of cooperation, because it strengthens relationships and responsibilities for one's own and the group's work, thus leading to improved readiness in collective tasks and critical evaluation of work done. It is a procedural component (one of the three practical components of inclusive education: organisational, procedural and instructional), which integrates various professionals - teaching and non-teaching school staff, who work together on planning and implementing programmes for various pupils in the mainstream environment says Harris, 1990; Porter, Wilson \& Kelly, 1991, Pugach \& Jonson, 1990 [in 4]. Sociopsychological and pedagogical research studies confirm that a change in the arrangement of human relationships on the principles of joint work contributes in many ways to the application of different parameters that can be described as promising:

$$
\begin{aligned}
& \text { i. highlighting the humanistic dimension in the } \\
& \text { relationship; } \\
& \text { ii. personality and social aspect; } \\
& \text { iii. strengthening a democratic, participatory relationship }
\end{aligned}
$$
ii. personality and social aspect;
iii. strengthening a democratic, participatory relationship [48].

The most common form of cooperation at school are spontaneous discussions about problems in pedagogical practice and mutual visits to lessons, observations in classes, but these also include meetings of the subject and methodological commission, 
focused on solving issues in the given teaching subject. The professional public emphasises the cooperation of teachers also outside of teaching subjects, such as organising pedagogical boards, operating councils, use of mentoring, team teaching, observations in classes, peer observations and reviews, supervision, coaching or consultations as other possible forms of collegial support for teachers' professional development.

How do the various forms help in meeting the specific needs of teachers working with pupils from a disadvantaged backgrounds or at an inclusive school?

Observations in classes - these are the most common form of collegial support. In practice, observations in classes are perceived more as a form of checking and supervision over a teacher's work, though from another aspect they be a means toward teachers' professional development, a form of assistance. It is mainly the school principal who uses observations in classes as a control instrument. Individual teachers can also visit one another for the purpose of observations in classes. This may be either a kind of requested visit for getting feedback on one's own teaching activity from a colleague from the field, or from professionally older colleagues for whom it is a way of transferring experience with methods and forms of pedagogical work. In the case of working with SEN pupils, this form of experience and advice transfer is particularly beneficial and advantageous for younger colleagues.

Mentoring- the goal of mentoring cooperation is to develop skills and knowledge, better quality professional competences, and achieve emotional stability, healthy self-confidence, but also the desired development of the atmosphere at school [49]. There are several forms of mentoring, though in mutual relations between the mentor and mentee, we can distinguish define formal and non-formal mentoring. In the case of non-formal mentoring, it is a relationship based on loyalty between individual subjects in their trust, loyalty and respect for one another. There is no set structure here and, in contrast to formal mentoring (which may be requested by a third party and paid for), mentoring is not overseen by any institution. Mentors do not undergo any training and are not financially rewarded. Another form of mentoring is, for instance, individual mentoring, which can be further divided into peer mentoring and reverse mentoring. Peer mentoring is performed in the framework of one generation without age differences [51].

Team teaching-This can be described as teaching in which one class is taught by several teachers at the same time (e.g. two teachers, an experienced teacher and a beginner teacher, colleagues, methodologists, a master of vocational training and teacher, special education teacher and teacher, etc.). In the case that it is taught by only two teachers, this can be described as pair / tandem teaching. The positive factors of team teaching lie in its beneficial effect on the professional development of teachers because of the ongoing mutual interaction here, during which teachers share their own opinions and present their own teaching methods in front of others [18]. This concept is based on mutual support and help between teachers, where adaptability and mutual cooperation play an important role. A benefit of teamwork [52] is, for example: encouraging the initiative of all members of the teaching staff and their engagement in fulfilling the goals and vision of the school, and taking responsibility for tasks; improving relationships and the overall improvement of the social climate at school and developing teachers' communication skills, especially openness in expressing opinions and feelings; - the creation of they wider space for the involvement of parents and pupils in work on school tasks, in creating a vision; and - their involvement in solving problems and taking opportunities in the case of pupils with special educational needs. Teamwork among school staff represents for pupils a model of collegial, partnership cooperation of the teaching community [53] in the form of democratic governance.

Coaching-This is a method that supports the personal development of the individual, own self-awareness, skills and abilities, similarly as in the case of mentoring [54]. This is the highest level of relations between the employee and the employer, in education it is between the teacher and the school management. The employer represents the motivator and the employee is the motivated one who has the possibility to independently choose his/her own goals and ways to achieve them. In the teaching profession, at the individual level, individual coaching is most applicable, taking place at the level of the coach and the learner [55]. What is the difference between mentoring and coaching? During mentoring, the mentor passes his/her know-how on to the mentee and shows him/her how good practice works on specific examples. In coaching, the learner must choose his/her own path and the coach has the role of an accompanying entity who respects the learner's goals.

Counselling-Counselling is external support for career growth, usually limited in time, thanks to participation in a project. In the Slovak school environment, however, there are consultants providing methodological and counselling support to teachers who find themselves in a problematic or otherwise difficult professional or life situation. The most used services are those of school counsellors, such as school psychologists, special education teachers or educational consultants, intervention specialists, etc. [49]. Collegial counselling also has its limits, these being mainly employees' resistance to proposals coming from the management, or "forced collegiality" and "differential cooperation", on the basis of assembly into formal groups (e.g. also according to sympathies). For collegial support to be implemented successfully so that it results in the desired improvement of teaching processes in school facilities, it is essential that the school management create a suitable atmosphere.

\section{Situation in Today's School - A Small Example from School Practice}

How teachers perceive the situation in terms of needs in current practice will be shown in the results of the preliminary research, which was carried out in 2019 by J. Trnavský [18] as part 
of his graduation thesis, at two Moravian secondary vocational schools in the Czech Republic, which are comparable to the situation in Slovakia, on a sample of 8 teachers. Interviews with them showed that working with socially-disadvantaged pupils means an increased burden for six of them. All of them considered disadvantaged backgrounds where their pupils come from to mean:

a) the poverty of the family; followed by

b) conflicts in the family and lack of interest in the pupil; and

c) lack of interest in his/her school; followed by

d) the difference between the mother tongue and the official language; and lastly

e) belonging to a different nationality and ethnic group.

The characteristic behaviours of pupils from disadvantaged social backgrounds were ranked by the teachers as follows: 1. indiscipline; 2 lack of interest in education and learning; 3. communication differences and absence of teaching aids at school; 4. increased aggression and disturbance in classes; 5. neglected appearance and passive attitude; and 6. the pupil overtiredness and lack of general knowledge. Teachers, who have in their class both intact and SEN pupils, have usually been teaching for a longer time, i.e. have a longer experience, experience more demanding work performance and need different preparation for a lesson. If teachers are constantly under some pressure and feel a burden (and have low-level resilience), they burn out faster. Therefore, it is positive to know their specific needs and to meet and satisfy them appropriately.

In the form of a semi-structured interview and a questionnaire, J Trnavský [18] identified the following specific needs of teachers (ranked by importance that teachers assigned to individual needs): 1. the need for further learning (in general) and better financial evaluation (a long-term problem in Slovakia) - as this concerns also work with SEN pupils, making further learning in this area ever more relevant. 2. the need for mentoring and regular psychological counselling - teachers most frequently use the services of a school psychologist in the field of mental hygiene, because the teaching profession is psychologically very demanding when working with adolescents, especially adolescents from socially disadvantaged backgrounds. 3. the need to have extracurricular activities that could lead to better relationships among the teaching staff, but also better relationships with pupils. 4 . the need for collegiality; 5 . the need for supervision and the need for sufficient free time and its effective use - ranked last in this list. We are aware that this is a small sample, though it was preliminary research focused on verifying the questionnaire.

\section{Conclusion}

In order to take full advantage of equal opportunities for education, it is necessary to support the creation of a stimulating and functional environment for learning and for working in the school environment for everyone. For interconnected learning and the ability to use information learned in different contexts, it is essential to create a learning environment that stimulates the development of knowledge, but also the ability of pupils to apply this knowledge in real practice, encourage curiosity and discovery, innovation and change. This requires change both in teachers' attitude, especially in fulfilling their specific needs, as covered in this study, and change in the internal environment of classes and schools so that pupils (including those from disadvantaged social backgrounds) have the opportunity to learn directly in the class and school in various manners of organisation, using variable methods, with various available education resources materials and teaching aids, labs and lab equipment, as well as relevant IT equipment. The learning environment should enable the application of teaching strategies that support the active position of the learner and enable the unhindered fulfilment of each child's potential (including the removal of physical barriers for pupils with disabilities). The environment should support the development of key competencies of both teachers and pupils, which is associated with the requirement to create a multidimensional space in which pupils should be able to work independently, think about links and connections, interact with other pupils or experts (e.g. also virtually) in solving various problems or in publishing their progress. At the same time, the multidimensional environment should create a space for relaxation for the teacher as well. The learning environment should not be merely limited to the physical environment of the school, but should be understood to include the immediate or wider vicinity of the school (including parks, forests, museums, libraries, zoological or botanical gardens, specialised laboratories, etc.) and various work environments (craft workshops, businesses, companies, offices, etc.), which would bring a qualitative change in the lives of teachers and pupils. Gradually, a virtual environment should become part of the learning environment, for situations (such as the current COVID-19 pandemic and other threats) that would enable effective fulfilment of educational goals and confirm the ability and resilience of teachers and pupils. And this is currently happening both in Slovakia and around the world. The results are not yet known, but research is already being conducted.

\section{Acknowledgement}

The theoretical study is a partial output of the solution of the Project VEGA 1/0142/19 DTI- 2019- 2021, Psychoeducational dimension of the inclusion of secondary school pupils, supported by the Ministry of Education, Slovakia, EU.

\section{References}

1. sAnderson Lorin W (1996) International Encyclopedia of Teaching and Teacher Education. Elsevier Science. Oxford, United Kingdom, pp. 344-348. 
2. Efimenko E, Roman A, Pinto M, Remiao F, Teixeira P (2018) Enhancement and Recognition of Teaching and Learning in Higher Education: The Impact of Teaching and Excellence Prizes. In: Journal of the European Higher Education Area 2: 100-106.

3. Ramberg J, Lénárt A, Watkins A (2018) European Agency Statistics on Inclusive Education: 2016 Dataset Cross-Country Report. European Agency for Special Needs and Inclusive Education, Odense, Denmark.

4. Stainback S, Stainback W (1996) Inclusion A Guide for Educators. Brookes Publishing, Maryland, United States,

5. Stern E (2017) Individual differences in the learning potencial of human beings. Science of learning, 2(2017): 1-7.

6. Bartoňová M, Vítková M (2007) Strategie ve vzdělávání dětí a žáků se speciálními vzdělávacími potřebami. Paido, Brno, Europe.

7. Zelina M (2019) Východiská inkluzívnej edukácie rómskych detí. Prevencia 1(2019): 3-9.

8. Wade S (2000) Inclusive Education: A Casebook and Readings for Prospective and Practicing Teachers. Lawrence Erlbaum, London, United Kingdom.

9. Barabási T, Dósa Z (2019) Külömbözőség psichológiája és differenciáló pedagógia. Kolozsvári Egyetemi Kiadó. Kolozsvár: Romania.

10. Lechta V (2010) Dítě s postižením, narušením, ohrožením versus intaktní dítě. In: Lechta V (Ed.), Základy inkluzívní pedagogiky. Dítě s PNO ve škole Portál, Praha, Europe, p. 29

11. Horňáková M (2006) Inklúzia - nové slovo, alebo aj nový obsah? Efeta, $1 / 16$, pp. $2-5$.

12. Merz-Atalik K (2006) Integration und Inklusion. In: Hansen G, Stein R (Eds.), und koll.: Kompendium Sonderpädagogik . Klinkhardt. Bad Heilbrunn, Germany, pp. 248-260.

13. Mittler P (2000) Working toward inklusive education. David Fulton Publishers, London, United Kingdom.

14. Barnová S (2019) Inklúzia, inkluzívna edukácia a inkluzívna škola v aktuálnom ponímaní. Týn nad Vltavou-Malá Strana.

15. Felcmanová L, Habrová. M (2015) Katalog podpůrných opatření: dílčí část : pro žáky s potřebou podpory ve vzdělávání z důvodu sociálního znevýhodnění. Univerzita Palackého v Olomouci, Olomouc, Europe. ISBN 978-80-244-4655-4.

16. Hanuliaková J, Porubčanová D (2016) Stress of Students and SocialPathological Phenomena. US-China Foreign Language 14(10): 723741.

17. Yener Ö (2020) My Learned Helplessness is Accelerating to SelfHandicapping. Psychol Behav Sci Int J 14(3): 555895.

18. Trnavský J (2020) Specifické potřeby učitelů středních odborných škol při práci se žáky ze sociálně znevýhodněného prostředí. DT Dubnica n/V: VŠ DTI.

19. Průcha J (2009) Pedagogická encyklopedie. Portál, Praha, Europe. ISBN 978-807-3675-462.

20. Hanuliaková J, Hapalová M (2019) Takmer polovica detí so špeciálnymi výchovno-vzdelávacími potrebami sa vzdeláva $\mathrm{v}$ špeciálnom prúde vzdelávania. In: Hall Analýza zistení o stave školstva na Slovensku: To dá rozum. Bratislava: MESA 10.

21. Vančíková K (2019) Žiaci, ktorým sa v škole darí menej, majú obmedzené možnosti získat' kvalifikáciu. In: Hall R. et al. Analýza zistení o stave školstva na Slovensku: To dá rozum. Bratislava: MESA10, Dostupné na.

22. Matuška O (2010) Inkluzívní didaktika-základní vymezení. In: Lechta V (ed.) Základy inkluzívní pedagogiky. Dítě s PNO ve škole. Portál, Praha, Europe.
23. Levterova D (2011) Teachers' perception of the children with special educational needs. In: Wiegerová, A Vávrová S (Eds.), Teacher's Thinking and Reasoning. Bratislava, Europe.

24. Geršicová (2015) Osobnostná a sociálna výchova ako súčast' práce triedneho učitela. In: GERŠICOVÁ, Z. et al. Osobnostná a sociálna výchova v edukačných súvislostiach [elektronický zdroj] Tribun EU s.r.o, Brno, Europe pp. 160-223.

25. Geršicová Z (2016) Class teachers - Their thinking and reasoning in the context of cerating a favourable classroom social climate by means of the metods of personal and social education. Acta Technologica Dubnicea 6(1): 27-41.

26. Palun M, Marks I (2016) The economic prosperity, managment and social possibilities of HNA. Tribun EU, Brno, Europe.

27. Kalhous Z, Obst O (2002) Školní didaktika. Portál, Praha, Europe.

28. Pellegrino JW (2014) Assessment as a positive influence on 21st century teaching and learning: A system Approach to progress. Psicologia Educativa 20(2014): 65-77.

29. Graham S, Hebert M, Harris K (2015) Formative assesment and writing:A meta-analysis. The Elementary school Journal 115(4): 523547.

30. Akpan GA, Essein EO, Okure SO (2013) Conceptual analysis and implications of studentś individual differences to curriculum implementation in technical education. International Education Studies 6(3): 156-161.

31. Putnam JA (1991) Curriculum adaptations for students with disabilities in cooperative groups. Cooperativ learning. IASCE, Santa Crus, United States.

32. Lang G, Berberichová CH (1998) Každé dítě potřebuje speciální přístup. Vytváření integrovaných a inkluzivních tříd. Portál, Praha, Europe.

33. Barnová $S$, Tamášová V, Krásna S (2019) The Role of Resiliencie in Coping with negative parental behaviour. Acta Educationis Generalis 2(9): 93-106.

34. Tomlison CA, Imbeau MB (2010) Leading and managing a differentiated classroom. ASCD, Alexandria: Egypt. ISBN 978-1-4166-1074-8.

35. Fortis E (2019) Manager's Personality and Their Professional Carrer. Acta Educationis Generalis 9(1): 28-46.

36. Tomková A (2012) Rámec profesních kvalit učitele: hodnoticí a sebehodnoticí arch. Národní ústav pro vzdělávání, Evaluační nástroje. Praha, Europe. ISBN 978-80-87063-64-4.

37. Tureckiová M (2009) Rozvoj a řízení lidských zdrojů. Univerzita Jana Amose Komenského, Praha, Europe. ISBN 978-80-86723-80-8.

38. Tamášová V (2015) Professional and Carrer Development of the Vocational Subject Teachers as a Trend in the Lifelong Learning of Teachers. Acta Technologica Dubnicea 5(1): 1-20.

39. Hlad'o P (2019) Carrer adaptibility of vocational education and training graduates in the period of prospective school-to-work transition. Studia paedagogica 24(2): 59-83.

40. Kasíková H (2010) Kooperativní učení, kooperativní škola. Portál Praha, Europe.

41. Cacciattolo K (2015) Defining workplace learning. University of Malta: European Scientific Journal, Dostupné

42. Castleton G, Gerber R, Pillay H (2004) Improving Workplace Learning: Emerging International Perspectives. Nova Science Publishers, New York, USA.

43. Evans K. (2006) Improving Workplace Learning. Routledge, London, United Kingdom. 


\section{Psychology and Behavioral Science International Journal}

44. Průcha J, Veteška J (2012) Andragogický slovník. Grada, Praha, Europe. ISBN 978-80-247-3960-1.

45. Průcha J (2017) Moderní pedagogika. Portál, Praha, Europe. ISBN 978-80-262-1228-7.

46. Rabušicová M, Brücknerová K (2016) Mezigenerační učení: teorie, výzkum, praxe. Masarykova univerzita, Brno, Europe.

47. Pol M (2007) Škola v proměnách. Brno: Masarykova univerzita, ISBN 978-80-210-4499-9.

48. Gillies RM (2000) The maintenance of cooperative and helping behaviours in cooperative groups. British Journal of Educational Psychology 1(70): 97-111.

49. Lazarová B (2006) Cesty dalšího vzdělávání učitelů. Paido, Brno, Europe.
50. Little WJ (1990) The mentor phenomenon and the social organization of teaching. Review of Research in Education 16: 297-351.

51. Brumovská T, Málková G (2010) Mentoring: výchova k profesionálnímu dobrovolnictví. Portál, Brno, Europe.

52. Senge PM, Roberts CH, Ross RB, Smith BJ, Kelner A (2009) The Fifth Discipline Fieldbook. Strategies and tools for building a learning organization.: Nicholas Brealey, London, United Kingdom.

53. Pedler M, Burgyone J, Boydell T (1999) The learning Company. A strategy for sustainable Development. MCGraw-Hill Book Company, London, United Kingdom.

54. Petrášová MA, Prausová I, Štěpánek Z (2014) Mentorink: forma podpory nové generace. Portál, Praha, Europe.

55. Horská V (2009) Koučování ve školní praxi. Grada, Praha, Europe.

\section{Your next submission with Juniper Publishers will reach you the below assets}

- Quality Editorial service

- Swift Peer Review

- Reprints availability

- E-prints Service

- Manuscript Podcast for convenient understanding

- Global attainment for your research

- Manuscript accessibility in different formats

( Pdf, E-pub, Full Text, Audio)

- Unceasing customer service

Track the below URL for one-step submission

https://juniperpublishers.com/online-submission.php 